\title{
Teknik Manajemen Stres yang Paling Efektif pada Remaja: Literature Review
}

\author{
Aulia Zikry Bunga Mentari, Ester Liana, Terry Y. R. Pristya \\ Program Studi S1 Kesehatan Masyarakat, Fakultas Ilmu Kesehatan, Universitas \\ Pembangunan Nasional Veteran Jakarta
}

\begin{abstract}
Abstrak
Teknik manajemen stres remaja adalah teknik untuk mengurangi atau menekan tingkat stres pada remaja. Prevalensi stres pada remaja di dunia mencapai angka yang memprihatinkan yaitu sekitar 5\%-70\%. Teknik manajemen stres bertujuan untuk menekan angka prevalensi stres pada remaja. Metode yang digunakan adalah literature review dan menggunakan Google Scholar dalam lima tahun terakhir. Hasil yang didapatkan 9.460 jurnal dengan kata kunci manajemen stres pada remaja, hasil tersebut disaring menjadi 5 jurnal. Hasil penelitian menunjukkan bahwa lima teknik manajemen stres pada remaja, yaitu problem focused coping, group discussion therapy, pendekatan konseling behavioral, emotional focus coping, dan guided imagery. Dari kelima teknik tersebut yang hasilnya paling efektif adalah guided imagery karena teknik ini membuat perasaan menjadi senang dan gembira akibat rangsangan respons perubahan psikofisiologis yang dilakukan pada teknik ini
\end{abstract}

Kata kunci: Efektivitas, Stres Remaja, Teknik Manajemen Stres

\section{Most Effective Stress Management Techniques in Adolescents: Literature Review}

\begin{abstract}
Adolescent stress management techniques are techniques for reducing or suppressing stress levels in adolescents. The prevalence of stress in adolescents in the world reaches an alarming number which is around 5\%-70\%. Stress management techniques have to purpose to reduces prevalence of stress in adolescents. A literature review is a method that is used and also Google Scholar in the last five years. The results obtained 9,460 journals with keywords stress management in adolescents, the results were filtered into 5 journals. There are five stress management techniques which is problem focused coping, group discussion therapy, approaching behavioral counseling, emotional focus coping, and guided imagery. Of the five techniques, the most effective result is guided imagery because this technique makes the feeling of being happy and happy due to the stimulation of the response to psychophysiological changes made in this technique.
\end{abstract}

Keyword: Effectiveness, Adolescent Stress, Stress Management Techniques

Korespondensi: Aulia Zikry Bunga Mentari

Email: auliazikrybunga@gmail.com 


\section{PENDAHULUAN}

Manusia memiliki fase dalam kehidupan, mulai dari bayi, anak-anak, remaja, dewasa dan pada fase terakhir adalah lansia (lanjut usia). Remaja merupakan fase paling penting dalam kehidupan manusia di mana remaja menggambarkan fase kehidupan yang menjadi masa transisi dari masa anak-anak menuju masa dewasa. Pada masa remaja banyak sekali perkembangan yang akan terjadi, baik itu perkembangan dari segi biologis, psikologis, dan sosial yang membuat remaja memiliki banyak potensi untuk perubahan kehidupan. Pada tahun 2015, proyeksi penduduk menunjukkan bahwa jumlah remaja di Indonesia yang berusia 10-24 tahun sudah mencapai lebih dari $25 \%$ atau sekitar 66,0 juta dari total jumlah penduduk. ${ }^{1}$ Dengan kata lain, dari empat orang penduduk terdapat satu remaja. Remaja merupakan harapan dan penerus dalam sebuah negara. Remaja atau generasi muda yang memiliki kepribadian yang disiplin dan cerdas dapat menguntungkan bagi negara dan berperan penting dalam membangun bangsa di masa depan. ${ }^{2}$

Stres adalah kondisi tidak nyaman yang timbul akibat lingkungan sekitar. ${ }^{3}$ Stres alah satu factor utama munculnya masalah sosial dan kesehatan. Stres yang berkelanjutan juga dapat berdampak pada masalah kesehatan jiwa seperti depresi, ansietas, putus sekolah, bahkan hingga bunuh diri. Seperti yang diketahui stres memiliki dampak negatif, maka dari itu cara manajemen stres sangat diperlukan untuk mengurangi dan mencegah stres yang dapat memicu dampak negatif. $^{4}$

Stres pada remaja di dunia terjadi pada negara maju maupun negara berkembang. Prevalensi stres dan kegelisahan pada remaja di dunia memiliki rentang mulai dari 5\%-70\%. ${ }^{5} \mathrm{Di}$ Amerika Serikat sendiri, 60\% korban bunuh diri menderita stres dan depresi. ${ }^{6}$ Selain itu, prevalensi stres pada remaja di Korea Selatan pada tahun 2019 diketahui mencapai 39,3\%. ${ }^{7}$ Sedangkan di Indonesia prevalensi stres remaja meningkat dari tahun ke tahun, yaitu mencapai $6,0 \%$ dari masyarakat. ${ }^{8}$ Mungkin angka 6\% masih terlihat kecil. Namun, dari tahun ke tahun angka tersebut selalu naik karena semakin banyak remaja yang terlibat bullying yang semakin marak terjadi dewasa ini. Maka dari itu, untuk meminimalisasi stres pada remaja dibuatlah aplikasi pendeteksi stres. ${ }^{9}$

Selain aplikasi manajemen stres seperti yang telah diuraikan sebelumnya, ada juga caracara atau teknik untuk meminimalisasi stres pada remaja yaitu dengan cara menulis diary book, tertawa, dan sebagainya. ${ }^{9}$ Berdasarkan uraian di atas, akan diteliti lebih lanjut mengenai teknik atau upaya apa saja yang dapat dilakukan untuk manajemen stres pada remaja.

\section{METODE}
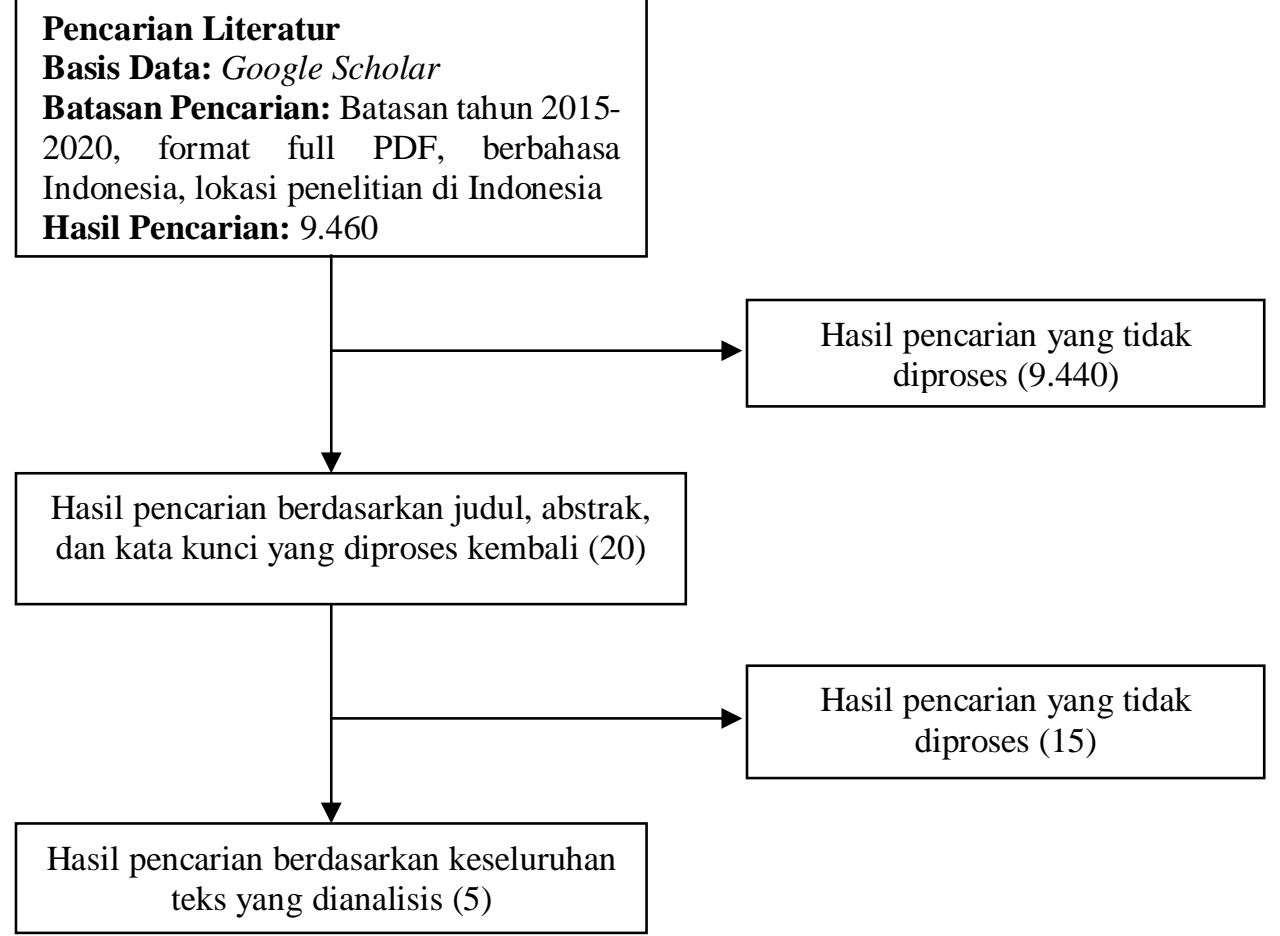
Metode Literature Review merupakan metode yang digunakan dalam penelitian ini. Penelitian dilaksanakan pada Februari sampai Maret 2020. Penelitian ini diperoleh dari laman Google Scholar dalam rentang waktu lima tahun terakhir (2015-2020). Jurnal yang digunakan memiliki versi full PDF, berbahasa Indonesia, dan melakukan penelitian di Indonesia. Hasil dari pencarian didapatkan 9.460 jurnal dengan kata kunci manajemen stres pada remaja. Hasil tersebut disaring menjadi 20 jurnal yang terkait dengan teknik manajemen stres pada remaja yang dilihat berdasarkan judul, kata kunci, dan abstraknya. Kemudian disaring kembali menjadi 5 jurnal yang terkait dengan manajemen stres pada remaja yang dilihat berdasarkan keseluruhan teksnya yang akan dijadikan penelitian dalam penulisan ini.

\section{HASIL}

Review ini mengkaji tentang teknik manajemen stres pada remaja. Terdapat lima jurnal yang dipilih dalam pengkajian kali ini. Karakteristik dari masing-masing jurnal akan dijelaskan pada Tabel 1.

Semua jurnal yang digunakan menggunakan uji eksperimen dengan rentang waktu penerbitan antara tahun 2015-2020. Teknik manajemen stres yang digunakan dalam masing-masing jurnal berbeda tergantung dengan sasaran remaja. Hasil kaji dari jurnal tersebut akan dijelaskan secara singkat pada Tabel 2.

Tabel 1. Karakteristik Artikel

\begin{tabular}{|c|c|c|c|c|}
\hline Penulis (Tahun) & $\begin{array}{c}\text { Jenis } \\
\text { Penelitian }\end{array}$ & $\begin{array}{c}\text { Tempat } \\
\text { Penelitian }\end{array}$ & Sampel Penelitian & Jumlah Sampel \\
\hline $\begin{array}{l}\text { Idris dan Pandang } \\
\text { (2018) }\end{array}$ & Experiment & $\begin{array}{c}\text { SMPN 1 } \\
\text { Gaselong Utara }\end{array}$ & $\begin{array}{l}\text { Siswa SMPN } 1 \\
\text { Gaselong Utara }\end{array}$ & 38 Orang \\
\hline $\begin{array}{l}\text { Mawaddah dan } \\
\text { Titiani (2016) }\end{array}$ & Experiment & $\begin{array}{l}\text { MTs Pesantren } \\
\text { Al-Amin } \\
\text { Mojokerto } \\
\end{array}$ & $\begin{array}{l}\text { Siswa MTs Pesantren } \\
\text { Al-Amin Mojokerto }\end{array}$ & 22 Orang \\
\hline Hartini (2018) & Experiment & $\begin{array}{l}\text { MTs Negeri } \\
\text { Prambanan }\end{array}$ & $\begin{array}{c}\text { Siswa MTs Negeri } \\
\text { Prambanan }\end{array}$ & 32 Orang \\
\hline $\begin{array}{c}\text { Berliana dan } \\
\text { Wardani (2017) }\end{array}$ & Experiment & $\begin{array}{l}\text { SMP Master Kota } \\
\text { Depok }\end{array}$ & $\begin{array}{c}\text { Siswa SMP Master } \\
\text { yang mencari } \\
\text { penghasilan di jalanan }\end{array}$ & 50 Orang \\
\hline $\begin{array}{l}\text { Sugiyanti, dkk } \\
\text { (2017) }\end{array}$ & Experiment & $\begin{array}{l}\text { SMK Kesdam IV } \\
\text { Kota Magelang }\end{array}$ & $\begin{array}{c}\text { Siswa SMK Kesdam IV } \\
\text { Kota Magelang }\end{array}$ & 25 Orang \\
\hline
\end{tabular}

Tabel 2. Teknik Manajemen Stres Pada Remaja

\begin{tabular}{|c|c|c|}
\hline Penulis (Tahun) & Jenis Penelitian & Hasil \\
\hline Idris dan Pandang (2018) & Experiment & $\begin{array}{c}\text { Problem Focused Coping dapat menurunkan tingkat } \\
\text { stres siswa terhadap mata pelajaran matematika. }\end{array}$ \\
\hline Mawaddah, dan Titiani (2016) & Experiment & $\begin{array}{c}\text { Adanya group discussion therapy dapat menurunkan } \\
\text { angka stres pada remaja. }\end{array}$ \\
\hline Hartini (2018) & Experiment & $\begin{array}{c}\text { Menggunakan teknik pendekatan konseling behavioral } \\
\text { berpengaruh dalam menurunkan angka stres pada } \\
\text { remaja. }\end{array}$ \\
\hline Berliana dan Wardani (2017) & Experiment & $\begin{array}{c}\text { Emotional Focus Coping yang paling sering digunakan } \\
\text { oleh anak jalanan di SMP Master Kota Depok }\end{array}$ \\
\hline Sugiyanti, dkk (2017) & Experiment & $\begin{array}{c}\text { Guided imagery dapat menurunkan tingkat stres pada } \\
\text { siswa yang mengalami boarding school, }\end{array}$ \\
\hline
\end{tabular}


Problem Focused Coping dilakukan selama tujuh pertemuan yang berisi pretest, pemberian teknik coping dan diakhiri dengan posttest. Problem Focused Coping dilakukan untuk membantu remaja dalam mencari penyebab stresnya dan cara menanganinya. ${ }^{10}$ Emotional Focus Coping merupakan teknik pengalihan stres dengan hal lain yang disenangi. Dalam kasus anak jalanan ini mereka mengalihkan stres merekadengan merokok, minum minuman keras, dan lainnya. ${ }^{11}$

Group Discussion Therapy juga bisa menjadi solusi untuk mengatasi stres. Group Discussion Therapy dibagi menjadi empat tahap, yaitu tahap modelling atau demonstrasi, role

\section{PEMBAHASAN}

Stres rentan dialami oleh remaja. Stres merupakan respons dari emosi yang tertekan yang dapat mengganggu kondisi kesehatan. ${ }^{9}$ Ada tiga tahapan dalam manajemen stres, yaitu 1) Tahap pertama yaitu mengetahui dan mengenali stres dan sumber stres yang mungkin muncul dalam kehidupan sehari-hari. 2) Tahap kedua yaitu mendapatkan dan mempraktekkan manajemen stres keterampilan coping yang telah dipelajari sebelumnya. 3) Tahap ketiga yaitu mempraktekkan teknik manajemen stres dalam masalah dalam kehidupan dan menilai keefektifannya. ${ }^{15}$ Hasil analisis menyatakan bahwa teknik manajemen stres memiliki banyak ragam. Teknik pertama adalah Problem Focused Coping. Problem Focused Coping merupakan teknik memberikan sebuah bantuan untuk memecahkan sebuah masalah. Problem Focused Coping memiliki beberapa teknik, yaitu coping aktif, suppression of competing activities, restraining coping, turning to religion, dan perencanaan. ${ }^{10}$ Problem Focused Coping digunakan untuk individu yang memiliki masalah seperti ancaman, gangguan, dan situasi yang menantang namun masih dapat berubah. ${ }^{16}$ Problem Focused Coping membuat individu merencanakan tindakan yang akan dilakukan untuk memperoleh apa yang diinginkan. ${ }^{17}$

Teknik kedua adalah Emotional Focus Coping. Emotional Focus Coping merupakan teknik manajemen stres dengan cara mengalihkan rasa stres. Rasa stres ini dialihkan dengan cara-cara yang mereka sukai. Umumnya Emotional Focus Coping digunakan oleh anak jalanan yang biasanya sering dikucilkan dan mendapatkan perlakuan buruk dari orang terdekat. ${ }^{11}$ Remaja yang mendapat perlakuan playing atau bermain peran, performance feedback atau unpan balik, dan transfer training atau implementasi dalam keseharian. ${ }^{12}$ Teknik pendekatan konseling behavioral menyebabkan perubahan perilaku siswa yang menyimpang. Teknik pendekatan konseling behavioral ini dapat membuat siswa melepaskan keluh kesahnya dan membantu siswa untuk memperbaiki perasaannya. ${ }^{13}$ Guided imagery merupakan teknik relaksasi yang dilakukan dengan membayangkan hal yang menurut penggunanya menyenangkan dan menenangkan. Dengan adanya keterbatasan imajinasi, maka guided imagery hanya dapat dilakukan menggunakan satu imajinasi yang paling kuat. ${ }^{14}$

buruk menginginkan simpati dari orang lain dan Emotional Focused Coping memungkinkan hal itu. ${ }^{17}$ Remaja yang menggunakan Emotional Focus Coping tergolong sebagai remaja yang masih belum bisa menyelesaikan inti masalah yang dihadapi. ${ }^{18}$

Selanjutnya ada teknik Group Discussion Therapy. Group Discussion Therapy merupakan suatu bentuk intervensi dalam bentuk kelompok yang nantinya akan diberikan stimulus untuk memecahkan masalah secara interpersonal. Group Discussion Therapy merupakan pengembangan dari terapi psikologis secara berkelompok. Group Discussion Therapy ini memiliki 3 sesi. Sesi pertama adalah sesi pengenalan dan sesi penilaian. Sesi kedua adalah diskusi terkait manajemen stres, dan sesi ketiga adalah evaluasi dan feedback dari Group Discussion Therapy. ${ }^{12}$

Selanjutnya ada teknik pendekatan behavioral. Teknik ini merupakan teknik di mana seseorang bercerita terkait masalah yang sedang dialami. Teknik ini biasa dipakai saat Bimbingan Konseling. Nantinya pembimbing akan menggiring siswa untuk menyelesaikan masalahnya sendiri. Namun masih banyak siswa yang bingung dan tidak nyaman saat menyampaikan keluh kesahnya. ${ }^{13}$ Teknik pendekatan behavioral dapat dilakukan bukan hanya saat bimbingan dengan pengajar namun bisa dilakukan dengan teman sehingga dapat bertukar pikiran. ${ }^{19}$

Teknik terakhir yang dianalisis adalah teknik Guided Imagery. Teknik ini digunakan dengan membayangkan hal-hal menyenangkan yang akan membuat perasaan kembali gembira dan tertata. ${ }^{14}$ Teknik ini dimulai dengan relaksasi 
selanjutnya pasien menutup mata dan fokus pada bayangan dalam pikirannya. ${ }^{20}$ Teknik ini bertujuan untuk merespon perubahan psikofisologis yang kuat seperti peningkatan imunitas dan dapat mengaktifkan saraf parasimpatis. Tingkat stres pada responden menurun walaupun penurunan tidak terjadi dalam jumlah besar namun hal ini cukup efektif dan efisien untuk menekan tingkat stres. Namun, sulit untuk membayangkan beberapa hal bersamaan. Maka dari itu disarankan fokus kepada satu hal menyenangkan dengan imajinasi paling kuat untuk mengoptimalkan hasilnya. ${ }^{14}$ Guided Imagery bukan hanya dapat mengurangi stres, namun juga dapat menghancurkan sel kanker, mengurangi rasa nyeri, dan untuk menenangkan pikiran. ${ }^{21}$

\section{KESIMPULAN}

Manajemen stres adalah suatu kegiatan mengatur stres yang ada dalam diri manusia sehingga stres tersebut tidak menjadi hal yang merugikan. Dalam manajemen stres ada beberapa cara atau teknik yang dapat dilakukan, yaitu : Problem Focused Coping, Discussion Group Therapy, Konseling Behavior, Emotional Focused Coping, dan Guided Imagery. Dari kelima teknik tersebut yang paling efektif dan efisien dalam memanajemen stres pada remaja adalah teknik Guided Imagery, karena pada teknik ini membuat perasaan menjadi senang dan gembira akibat rangsangan respons perubahan psikofisiologis yang dilakukan pada teknik ini. Sedangkan, teknik yang paling tidak efektif adalah Konseling Behavior karena banyak remaja yang malu dan bingung pada akhirnya teknik ini tidak efektif.

\section{DAFTAR PUSTAKA}

1. Badan Pusat Statistik. Statistik Pemuda Indonesia [Internet]. Jakarta: Badan Pusat Statistik; 2013 [dikutip 14 April 2020]. Tersedia pada: https://www.bps.go.id/publication/download. html?nrbvfeve=ZDMzYTI2MTk0YjU5ZGV IMDlmMDRkMjUz\&xzmn=aHR0cHM6Ly9 3d3cuYnBzLmdvLmlkL3B1 YmxpY2F0aW 9uLzIwMTQvMTAvMjkvZDMzYTI2MTk0 YjU5ZGVIMDlmMDRkMjUzL3N0YXRpc 3Rpay1wZW11ZGEtaW5kb25lc2lhLTIwM TMuaHRtbA\%3D\%3D\&twoadfnoarfeauf= MjAyMC0wNC0xNCAxNTozMjo0OQ\%3D $\% 3 \mathrm{D}$
2. Wahyuningtyas R. Etika Moral, Ujung Tombak Pemuda Saat ini [Internet]. Good News From Indonesia. 2019 [dikutip 13 Maret 2020]. Tersedia pada: https://www.goodnewsfromindonesia.id/201 9/12/10/etika-moral-pemuda

3. Prameswari V. Apa itu Stres dan Bagaimana Cara Mengatasinya? [Internet]. Zenius. 2017 [dikutip 12 Maret 2020]. Tersedia pada: https://www.zenius.net/blog/16996/mengatas i-stres

4. Willy T. Stres [Internet]. Alodokter. 2019 [dikutip 13 Maret 2020]. Tersedia pada: https://www.alodokter.com/stres

5. Sahoo S, Khess CRJ. Prevalence of depression, anxiety, and stress among young male adults in India: a dimensional and categorical diagnoses-based study. J Nerv Ment Dis [Internet]. Desember 2010 [dikutip 13 Maret 2020];198(12):901-4. Tersedia pada:

https://www.ncbi.nlm.nih.gov/pubmed/2113 5643

6. Cash SJ, Bridge JA. Epidemiology of Youth Suicide and Suicidal Behavior. Curr Opin Pediatr [Internet]. Oktober 2009 [dikutip 5 Mei 2020];21(5):613-9. Tersedia pada: https://www.ncbi.nlm.nih.gov/pmc/articles/P MC2885157/

7. KCDC. Trends in prevalence of psychological stress among Korean adolescents, 2007-2019 [Internet]. KCDC. 2020 [dikutip 6 Mei 2020]. Tersedia pada: http://www.cdc.go.kr

8. Balitbangkes. Riskesdas 2013 [Internet]. Jakarta; 2013 [dikutip 13 Maret 2020]. Tersedia pada: https://www.bps.go.id/publication/download. html?nrbvfeve=ZDMzYTI2MTk0YjU5ZGV IMDlmMDRkMjUz\&xzmn=aHR0cHM6Ly9 3d3cuYnBzLmdvLmlkL3B1YmxpY2F0aW 9uLzIwMTQvMTAvMjkvZDMzYTI2MTk0 YjU5ZGVIMDlmMDRkMjUzL3N0YXRpc 3Rpay1wZW11ZGEtaW5kb25lc2lhLTIwM TMuaHRtbA\%3D\%3D\&twoadfnoarfeauf= MjAyMC0wNC0xNCAxNTozMjo0OQ\%3D $\% 3 \mathrm{D}$

9. Suratmini D, Afriani T. Pemanfaatan Deteksi Stres Remaja Yang Efektif Dan Efisien Melalui Aplikasi: Systematic Review. J Keperawatan Respati Yogyak [Internet]. 2019 [dikutip 12 Maret 2020];6(1):542-7. Tersedia pada: https://scholar.ui.ac.id/en/publications/peman 
faatan-deteksi-stres-remaja-yang-efektif-danefisien-melalui

10.Idris I, Pandang A. Efektivitas Problem Focused Coping Dalam Mengatasi Stress Belajar Siswa Pada Pelajaran Matematika. J Psikol Pendidik Dan Konseling J Kaji Psikol Pendidik Dan Bimbing Konseling [Internet]. 25 Juni 2018 [dikutip 13 Maret 2020];4(1):63-8. Tersedia pada: https://ojs.unm.ac.id/JPPK/article/view/5896

11.Berliana, Wardani IY. Stres dan Strategi Koping Anak Jalanan di Kota Depok. J Persat Perawat Nas Indones JPPNI [Internet]. 31 Agustus 2018 [dikutip 13 Maret 2020];2(2):108-16. Tersedia pada: http://www.jurnalppni.org/ojs/index.php/jppni/article/view/88

12. Mawaddah N, Titiani E. Efektifitas Group Discussion Therapy Dalam Menurunkan Stres Remaja di MTs Pesantren Al-Amin Mojokerto. Medica Majapahit [Internet]. 17 Oktober 2016 [dikutip 3 November 2020];8(2):21-30. Tersedia pada: http://103.38.103.27/lppm/index.php/MM/art icle/view/112

13.Hartini S. Melalui Layanan Bimbingan Kelompok dengan Teknik Pendekatan Konseling Behavioral untuk Mengatasi Stres dan Depresi. Al Ghazali [Internet]. 10 Agustus 2018 [dikutip 13 Maret 2020];1(1):85-113. Tersedia pada: https://www.ejournal.stainupwr.ac.id/index.p hp/al_ghzali/article/view/24

14.Sugiyanti DA, Suhariyanti E, Priyanto S. Pengaruh Guided Imagery Dalam Menurunkan Stress Siswa Menghadapi Proses Boarding School di SMK Kesdam IV Kota Magelang. J Holist Nurs Sci [Internet]. 31 Juli 2017 [dikutip 13 Maret 2020];4(2):508. Tersedia pada: http://journal.ummgl.ac.id/index.php/nursing /article/view/1749

15.Hakim GRU, Tantiani FF, Shanti P. Efektifitas Pelatihan Manajemen Stres pada Mahasiswa. J Sains Psikol [Internet]. 11 Februari 2017 [dikutip 14 April 2020];6(2). Tersedia pada: http://journal2.um.ac.id/index.php/JSPsi/artic le/view/1641

16.Semaraputri SAKT, Rustika IM. Peran Problem Focused Coping dan Konsep Diri Terhadap Penyesuaian Diri Pada Remaja Akhir yang Menjadi Pengurus Organisasi Kemahasiswaan di Fakultas Kedokteran Universitas Udayana. J Psikol Udayana
[Internet]. 29 April 2018 [dikutip 5 Mei 2020];5(01):35-47. Tersedia pada: https://ojs.unud.ac.id/index.php/psikologi/art icle/view/39274

17.Iqramah $\mathrm{N}$, Nurhasanah $\mathrm{N}$, Bustamam $\mathrm{N}$. Strategi Coping (Problem Focused Coping dan Emotion Focused Coping) Dalam Menghadapi Stres Pada Mahasiswa Penyusun Skripsi FKIP Universitas Syiah Kuala. JIMBK J Ilm Mhs Bimbing Konseling [Internet]. 2018 [dikutip 5 Mei 2020];3(4):75-83. Tersedia pada: http://www.jim.unsyiah.ac.id/pbk/article/vie w/6209

18. Sujadi E, Wahab M. Strategi Coping Korban Bullying. Tarbawi J Ilmu Pendidik [Internet]. 5 Februari 2018 [dikutip 5 Mei 2020];13(2):21-32. Tersedia pada: http://ejournal.iainkerinci.ac.id/index.php/tar bawi/article/view/190

19. Konadi H, Mudjiran M, Karneli Y. Efektivitas Pendekatan Rational Emotive Behavior Therapy melalui Bimbingan Kelompok untuk Mengatasi Stres Akademik Siswa. Konselor [Internet]. 29 Desember 2017 [dikutip 5 Mei 2020];6(4):120-31. Tersedia pada: http://ejournal.unp.ac.id/index.php/konselor/ article/view/7887

20.Rahmayanti YN. Pengaruh Guided Imagery Terhadap Tingkat Kecemasan Pada Pasien Skizoafektif di RSJD Surakarta [Internet] [s1]. Universitas Muhammadiyah Surakarta; 2010 [dikutip 21 Mei 2020]. Tersedia pada: http://eprints.ums.ac.id/9482/

21.Afdila JN. Pengaruh Terapi Guded Imagery Terhadap Tingkat Stres Pada Mahasiswa Tingkat Akhir Dalam Menyelesaikan Skripsi [Internet]. [Surabaya]: Universitas Airlangga; 2017 [dikutip 5 Mei 2020]. Tersedia pada: http://repository.unair.ac.id/50614/ 